\title{
Fe-Zn INTERMETALLIC PHASES PREPARED BY DIFFUSION ANNEALING AND SPARK-PLASMA SINTERING
}

\author{
Fe-Zn INTERMETALNE FAZE, PRIPRAVLJENE Z DIFUZIJSKIM \\ ŽARJENJEM IN S SINTRANJEM V ISKREČI PLAZMI
}

\author{
Petr Pokorný1, Jakub Cinert ${ }^{2,3}$, Zdenek Pala ${ }^{2}$ \\ ${ }^{1}$ Czech Technical University, Klokner Institute, Solinova 7, 16608 Prague 6, Czech Republic \\ 2Institute of Plasma Physics, ASCR v.v.i., Za Slovankou 1782/3, 18200 Prague 8, Czech Republic \\ ${ }^{3}$ University in Prague, Faculty of Electrical Engineering, Department of Electrotechnology, Prague 6, Czech Republic \\ cinert@ipp.cas.cz
}

Prejem rokopisa - received: 2014-12-22; sprejem za objavo - accepted for publication: 2015-03-10

\author{
doi:10.17222/mit.2014.309
}

\begin{abstract}
The feasibility of iron-zinc intermetallic-phase preparation by spark-plasma sintering (SPS) was investigated. The samples were prepared with a combination of powder metallurgy, where the powder was prepared in evacuated quartz tubes, and a sintering process using SPS. Since the Fe-Zn intermetallic phases are mostly used for hot-dip galvanized steels, the knowledge of the properties of individual intermetallic phases is vital for a better understanding and even further optimization of galvanization processes. The main aim of the article is to compare the phase composition of the initial powder with the SPS samples using $\mathrm{X}$-ray diffraction. Furthermore, the hardness and microstructure were investigated as well.

Keywords: Fe-Zn intermetallics, spark-plasma sintering, diffusion annealing, phase composition, hardness
\end{abstract}

Preučevana je bila izvedljivost priprave železo-cink intermetalnih faz s sintranjem v iskreči plazmi (SPS). Vzorci so bili pripravljeni s pomočjo metalurgije prahov, kjer so bili prahovi zaprti v evakuirane kvarčne cevi, ki mu je sledil postopek SPS Ker se Fe-Zn intermetalne faze večinoma uporablja pri vročem cinkanju jekel, so lastnosti posamezne faze pomembne za boljše razumevanje in celo za optimiranje procesa galvanizacije. Glavni namen članka je primerjava sestave faz s pomočjo rentgenske difrakcije v začetnih prahovih in SPS vzorcih. Preiskovani sta bili tudi trdota in mikrostruktura.

Ključne besede: Fe-Zn intermetalne zlitine, sintranje z iskrečo plazmo, difuzijsko žarjenje, sestava faz, trdota

\section{INTRODUCTION}

Hot-dip galvanized coating is one of the most common protection surfaces of low-alloy steels as it offers a good corrosion protection under normal atmospheric conditions. During a hot-dip galvanizing process, iron-zinc diffusion coating grows on the surface of galvanized steel. This coating consists of a specific intermetallic formation, in which the iron content decreases ${ }^{1}$ towards the galvanized steel giving rise to a sequence ${ }^{2}$ of $\mathrm{Fe}-\mathrm{Zn}$ intermetallic phases. These new phases are joined with the substrate and with each other by a system of elementary intermetallic bonds. ${ }^{3}$ Individual phases are different in composition, structure, morphology, thickness and mechanical properties. ${ }^{4}$

Both the composition and the thickness of the coating depend on impurity elements concentrations in the galvanized steel, composition and temperature of the galvanized zinc bath, time of submersion, thickness of galvanized profiles, mechanical and thermal processing of the galvanized steel and the cooling process after the coating deposition. ${ }^{2}$ There is an unevenly thick layer of galvanized zinc, or the so-called $\eta$ phase representing the substitutional solid solution of iron in zinc, on the surface. The $\eta$-phase layer fosters the galvanizing process by facilitating the formation of specific intermetallic galvanized layers. These layers provide a good protection against the corrosion and an increased resistance to wear because the intermetallic phases are harder than the $\eta$ phase. $^{2}$

With respect to the mechanical properties of intermetallic phases, the microhardness and compressive strength $^{5,6}$ have mostly been analysed. According to single-crystal hardness studies, ${ }^{7}$ the highest hardness is achieved by $\delta$ and $\Gamma_{1}$ phases. The results of the studies clearly prove that the $\Gamma_{1}$ phase is the hardest phase in the hot-dip galvanized coating. It has also been shown ${ }^{6}$ that the compression strength and hardness decrease with the increasing hardness, hence, the $\delta$ and $\Gamma_{1}$ phases are relatively fragile. Both $\delta$ and $\Gamma_{1}$ phases do not experience plastic deformation after exceeding the yield stress; instead a brittle fracture occurs. ${ }^{2}$ On the other hand, it is possible to plastically deform the $\Gamma$ phase up to the elongation of $2.2 \%{ }^{8}$ For the $\zeta$ phase, the elongation is only $0.5 \%$. ${ }^{9}$ The values of the microhardness and compressive strength for each $\mathrm{Fe}-\mathrm{Zn}$ intermetallic phase are shown in Table 1.

In our contribution, we have striven to analyse the hardness of the $\delta$ and $\Gamma$ phases, i.e., one brittle and one ductile phase, prepared by spark-plasma sintering. ${ }^{10}$ The preparation of the powders for individual intermetallic phases is relatively complicated. We took the path of sealing the powder in an evacuated quartz ampoule followed by a diffusion annealing process. ${ }^{11,12}$ 
Table 1: Mechanical properties of Fe-Zn intermetallic phases Tabela 1: Mehanske lastnosti Fe-Zn intermetalnih faz

\begin{tabular}{|c|c|c|c|}
\hline Phase & Formula & Hardness, HV & Stress-strain condition \\
\hline$\eta$ & $\mathrm{Zn}$ & 52 & - \\
\hline$\zeta$ & $\mathrm{FeZn}$ & 208 & ductile $(\varepsilon=0.5 \%)$ \\
\hline$\delta$ & $\mathrm{FeZn}_{10}$ & 358 & brittle \\
\hline$\Gamma_{1}$ & $\mathrm{Fe}_{5} \mathrm{Zn}_{21}$ & 505 & brittle \\
\hline$\Gamma$ & $\mathrm{Fe}_{3} \mathrm{Zn}_{10}$ & 326 & ductile $(\varepsilon=2.2 \%)$ \\
\hline
\end{tabular}

\section{EXPERIMENTAL PART}

The Fe-Zn intermetallics were prepared with the powder-metallurgy technique. First of all, iron powder (iron-powder, Sigma Aldrich, particles size $<150 \mu \mathrm{m}$, purity of mass fractions of $100 \% \mathrm{Fe}$ ) and zinc powder (zinc powder, AlfaAesar, the median particle size of 6-9 $\mu \mathrm{m}$, purity of mass fractions of $99 \% \mathrm{Zn}$ ) were mixed under appropriate conditions of the atomic ratio. These mixtures $(\Gamma$ and $\delta$ ) were compressed with $50 \mathrm{kN}$ using a Heckert FPZ 100/1DO universal loading machine, into forms with a diameter of $10 \mathrm{~mm}$. The obtained samples were sealed into pre-evacuated quartz ampoules. The sealed samples were diffusion annealed at $50{ }^{\circ} \mathrm{C}$, below their thermal stability, as shown on Figure 1. The duration of diffusion annealing was $12 \mathrm{~h}$ and the heating rate was $5^{\circ} \mathrm{C} / \mathrm{min}$.

After the diffusion annealing, the powder was removed from the quartz tubes and sintered with the rapid SPS technique. Each sample was made from $9 \mathrm{~g}$ of the specific phase powder. The temperature rate was 100 ${ }^{\circ} \mathrm{C} / \mathrm{min}$; $100{ }^{\circ} \mathrm{C}$ bellow the maximum sintering temperature, the temperature rate decreased to $50{ }^{\circ} \mathrm{C} / \mathrm{min}$. After the maximum temperature of the sintering was achieved, a force of $60 \mathrm{MPa}$ was applied to the samples and the holding time was $5 \mathrm{~min}$. The values measured during the sintering process are in Figure 2.

Powder X-ray diffraction (PXRD) was employed to ascertain the phase compositions of the feedstock mate-

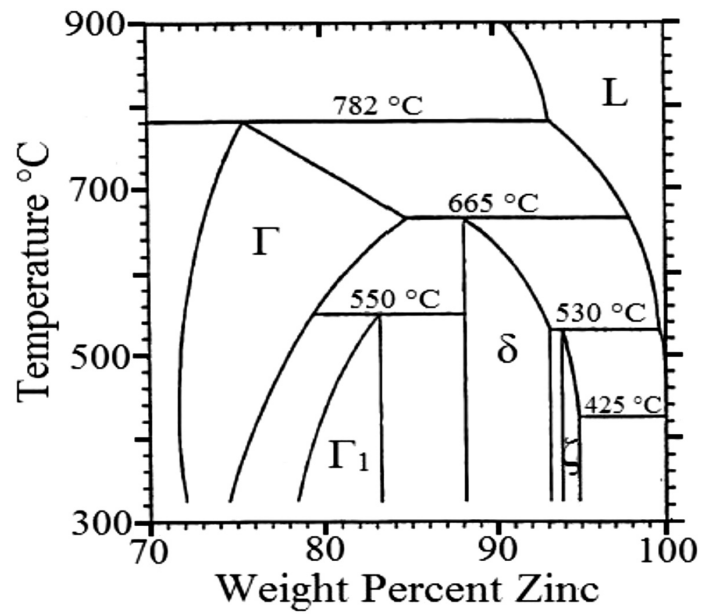

Figure 1: Detail of phase diagram $\mathrm{Fe}-\mathrm{Zn}$ defining intermetallic phases created by hot-dip galvanizing ${ }^{2}$

Slika 1: Detajl faznega diagrama Fe-Zn, ki določa intermetalne faze, nastale pri vročem cinkanju ${ }^{2}$

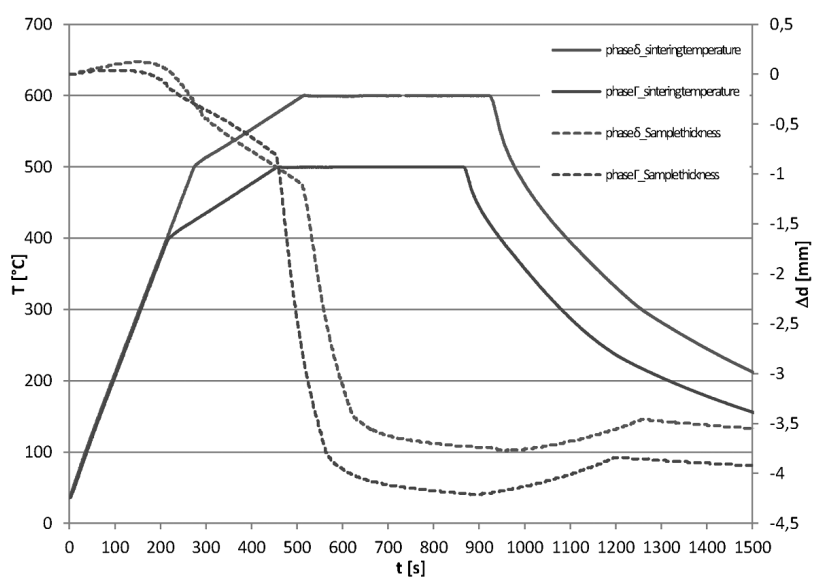

Figure 2: Courses of the temperature (full lines) and changes in the samples' thickness (dotted lines) during SPS of both samples

Slika 2: Potek temperature (polni črti) in spremembe $v$ debelini vzorca (prekinjeni črti) med SPS obeh vzorcev

rials and sintered samples. The samples were mounted onto the $x, y, z$ positioning stage of a D8 Discover diffractometer in the Bragg-Brentano geometry, equipped with a 1D LynxEye detector (Bruker AXS, Germany) and inspected with $\mathrm{Cu}-K \alpha$ radiation. After the identification of crystalline phases, the CIFs (crystallographic information files) were taken from the ICSD (the Inorganic Crystal Structure Database) and the COD (the Crystallography Open Database) containing 13 and 2 files for the Fe-Zn systems, respectively. The obtained PXRD patterns were subjected to the Rietveld analysis in the TOPAS 4.2 software. Utmost care was taken to follow the guidelines for measuring and data evaluation. ${ }^{13}$

The microstructures of the sintered samples were observed with a scanning electron microscope, Carl Zeiss SMT, EVO MA 15. Hardness measurements were performed on polished surfaces using Innovatest Nexus with a Vickers indenter with a force of $0.1 \mathrm{~kg}$, i.e, HV0.1, and a dwell time of $10 \mathrm{~s}$ according to EN ISO 6507-1. The hardness was tested twelve times in different places across the lengths of the polished surfaces.

\section{RESULTS AND DISCUSSION}

In Figure 3, both the $\Gamma$ powder after the diffusion annealing and its sintered sample contained only two phases, i.e., zincite $(\mathrm{ZnO})$ and the $\Gamma$ phase. The $\Gamma$ phase is bcc with the $\gamma \mathrm{Cu}_{5} \mathrm{Zn}_{8}$ brass type and $I \overline{4} 3 \mathrm{~m}$ space group. Concerning the stoichiometry, Brandon et al. ${ }^{14}$ indicate that it is $\mathrm{Fe}_{3} \mathrm{Zn}_{10}$ (ICSD code 2094), Belins ${ }^{15}$ give $\mathrm{Fe}_{13} \mathrm{Zn}_{39}$ (ICSD code 150198) and Johansson et al. ${ }^{16}$ give $\mathrm{Fe}_{4} \mathrm{Zn}_{9}$ (ICSD code 103708). Employing the CIFs for all these four stoichiometries, we obtained virtually the same refined lattice parameter of $a=0.8972 \mathrm{~nm}$, but the correspondence between the structural model and the measured data was the best for the $\mathrm{Fe}_{13} \mathrm{Zn}_{39}$ stoichiometry. The result of the Rietveld refinement of the $\Gamma$ feedstock powder is in Figure 4. When comparing the 


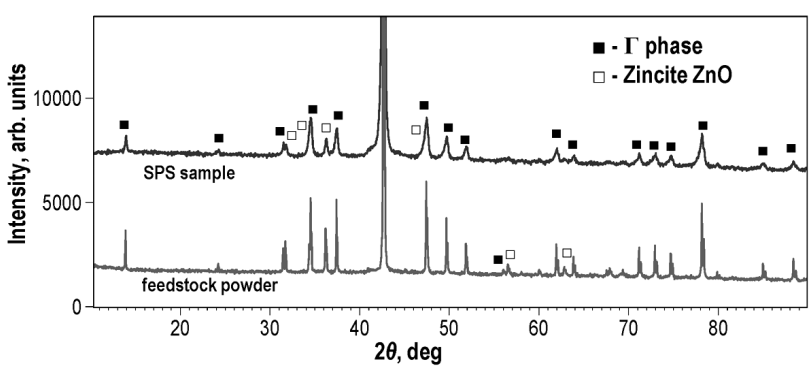

Figure 3: PXRD patterns of $\Gamma$ feedstock powder and sintered sample. Vertical shift was introduced to make the features of both patterns distinguishable.

Slika 3: Rentgenograma prahu $\Gamma$ surovca in sintranega vzorca. Vertikalni zamik je izvršen zaradi prikaza obeh diagramov.

diffraction patterns from the viewpoint of profile analysis, the sintered sample exhibited markedly smaller crystallite sizes whose average value was $30 \mathrm{~nm}$, as determined with the Rietveld refinement. This result is mirrored by the broader diffraction profiles of the sintered-sample PXRD pattern. The microstructure of the metallographic specimen of the sintered sample is in Figure 5.

For the $\delta$ feedstock powder and the sintered sample, the PXRD patterns contain a fairly large number of reflections, which have the same $2 \theta$ positions, but are significantly broader for the sintered sample, as seen in Figure 6. During the phase identification, the presence of zincite and hexagonal phase of the Fe-Zn system was established in both patterns. There are only two phases with such a structure, one in the ICSD with code $150199^{15}$ and one in the COD with code $2105806 .{ }^{17}$ Of these two, the former leads to a better fit; however, the fit was not satisfactory for the lower $2 \theta$ range where the used CIFs indicated the presence of more reflections than observed. Since both CIFs are relevant for the so-called $\delta_{1 \mathrm{p}}$ phase, the results of the Rietveld refinement thus indicate that the present phase is $\delta_{1 \mathrm{k}}$. The microstructure of this sintered sample, which can be seen in Figure 7, is notable by a higher intergranular porosity

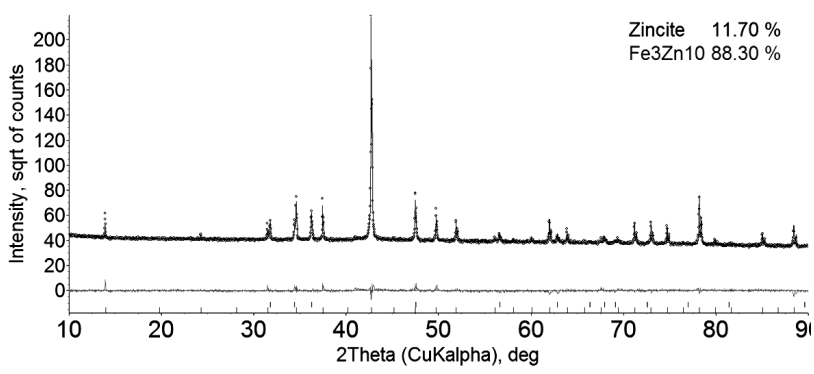

Figure 4: Result of Rietveld refinement of the feedstock powder. Dots are the measured data and the line is the fit. The grey curve at 0 intensity is difference between measured data and fit; $R_{\mathrm{wp}}=3.98$. Information about the quantitative presence of both phases in the top-right corner is in mass fractions $(w / \%)$.

Slika 4: Rezultati Rietveld udrobnjenja prahu $\Gamma$ surovca. Izmerjeni podatki so točke, črta so prilegajoči se podatki. Siva krivulja pri intenziteti 0 je razlika med izmerjenimi in prilegajočimi podatki; $R_{\mathrm{wp}}=$ 3,98. Podatki o kvantitativnem prikazu so v zgornjem desnem kotu v masnih deležih, $(w / \%)$.

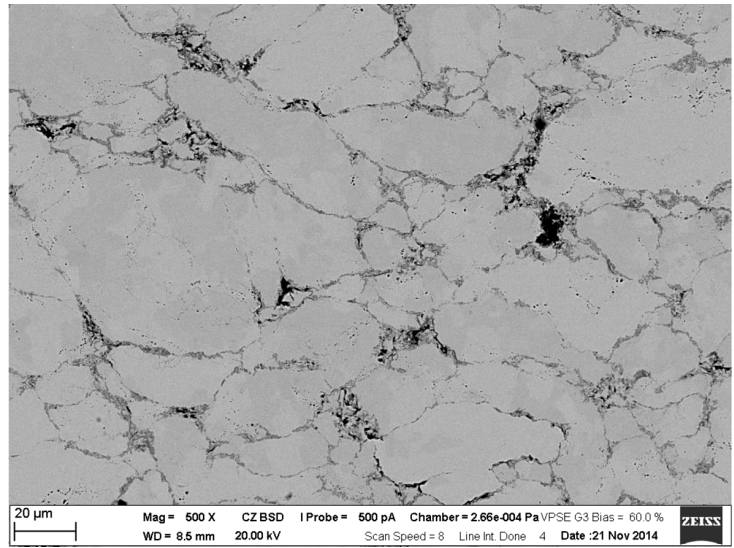

Figure 5: Microstructure of the $\Gamma$ phase of the spark-plasma-sintered sample

Slika 5: Mikrostruktura faze $\Gamma \mathrm{v}$ vzorcu, sintranem v iskreči plazmi

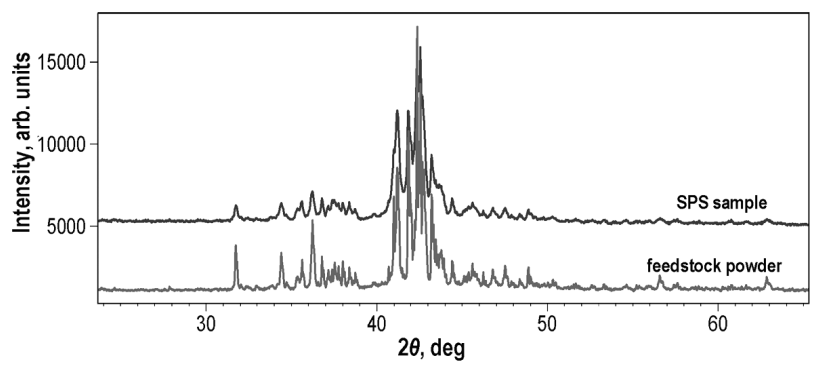

Figure 6: PXRD patterns of the $\delta$ feedstock powder and sintered sample. Vertical shift was introduced to make the features of both patterns distinguishable.

Slika 6: Rentgenograma prahu $\delta$ surovca in sintranega vzorca. Vertikalni zamik krivulj je izvršen zaradi boljše preglednosti krivulj.

when compared to the $\Gamma$ phase of the SPS sample. Moreover, while there are clearly visible particles of zincite (dark grey areas) in Figure 7, the oxide in the $\Gamma$ phase of the SPS sample is mostly seen around the Fe- Zn intermetallic grains.

The microhardness results are summarized in Figure 8 and they, indeed, show that the $\delta$ phase is generally about $10 \%$ harder than the $\Gamma$ phase, as indicated in Table 1. The obtained hardness values of the $\delta$ phase fall

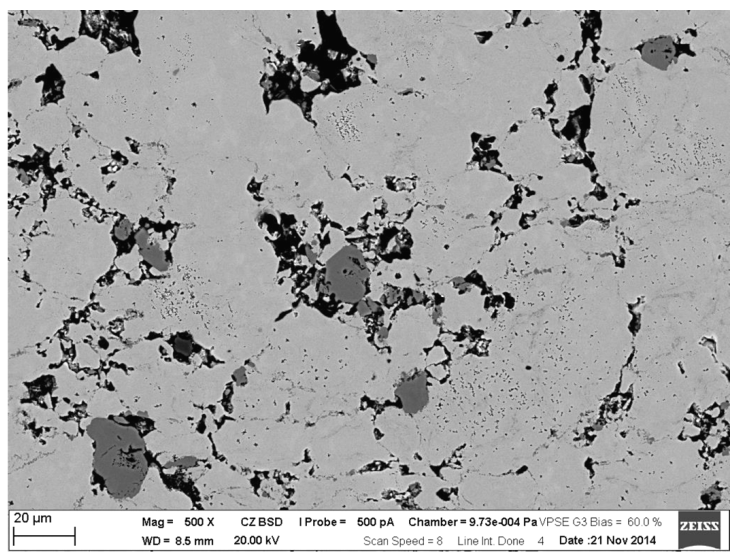

Figure 7: Microstructure of the $\delta$ phase of the spark-plasma-sintered sample

Slika 7: Mikrostruktura $\delta$ faze vzorca, sintranega v iskreči plazmi 


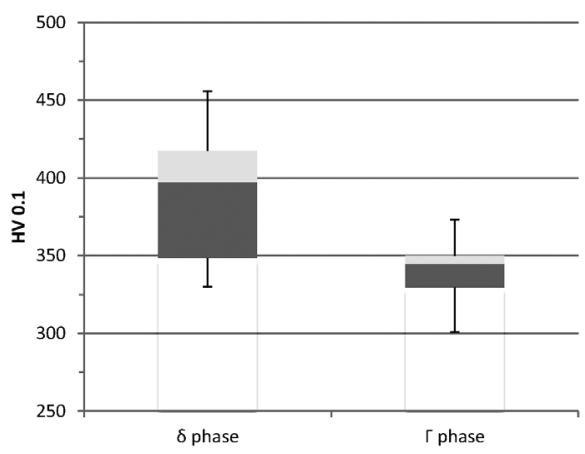

Figure 8: Microhardness results for the sintered-sample polished surfaces

Slika 8: Rezultati meritve mikrotrdote polirane površine sintranih vzorcev

within a comparatively broad range from $330 \mathrm{HV}$ to 460 $\mathrm{HV}$, which is probably due to the porosity. However, the values above $400 \mathrm{HV}$ are substantially higher than so far indicated for this phase.

The preparation of the pure Fe- $\mathrm{Zn}$ intermetallic phases, from the phase-composition point of view, can facilitate a better understanding of their properties. By using diffusion annealing in the pre-evacuated quartz ampoules and rapid sintering during the SPS process, compact samples with around $10 \%$ of mass fractions of zincite were obtained, with the remaining material being either the $\delta$ or $\Gamma$ phase. However, the zincite phase was already in the material after the diffusion annealing and, hence, the sintering process did not changed the phase composition. Moreover, the diffraction-profile analysis shows that a significant grain- or crystallite-size refinement took place during the SPS process. Concerning the presence of zincite and its effect on the hardness, microhardness mapping of the sintered samples' surfaces will be performed in our next study.

\section{CONCLUSIONS}

By applying diffusion annealing and spark-plasma sintering of Fe-Zn intermetallics, compact samples were obtained. After $5 \mathrm{~min}$ of sintering at $500{ }^{\circ} \mathrm{C}$ and $600{ }^{\circ} \mathrm{C}$ of the $\Gamma$ or $\delta \mathrm{Fe}-\mathrm{Zn}$ phases, respectively, no change in the phase composition was observed and only the grainrefinement phase took place. The level of zincite, or $\mathrm{ZnO}$, remained the same, at around $10 \%$ of mass fractions. Hence, spark-plasma sintering is a viable way of obtaining a system, where only one $\mathrm{Fe}-\mathrm{Zn}$ intermetallic is present.

The measured hardness of individual compact samples verifies the fact that the brittle $\delta$ phase is generally about $10 \%$ harder than the ductile $\Gamma$ phase. As for their microstructures, the brittle phase exhibits a higher intergranular porosity.

\section{Acknowledgments}

This research has been supported by Czech Science Foundation, Project GA ČR No P105/12/G059 and
Author Z. Author Z. Pala acknowledges the support of the Czech Science Foundation through project number 14-36566 Gentitled Multidisciplinary research centre for advanced materials.

\section{REFERENCES}

${ }^{1}$ C. Housecroft, A. G. Sharpe, Inorganic Chemistry, 4th Ed., Prentice Hall, 2012, p. 1256

${ }^{2}$ A. R. Marder, The metallurgy of zinc-coated steel, Prog. Mater. Sci., 45 (2000) 3, 191-271, doi:10.1016/S0079-6425(98)00006-1

${ }^{3}$ F. A. Cotton, G. Wilkinson, C. A. Murillo, M. Bochmann, Advanced Inorganic Chemistry, 6th Ed., Wiley, 1999, p. 1376

${ }^{4}$ N. N. Greenwood, A. Earnshaw, Chemistry of the Elements, 2nd Ed., Butterworth-Heinemann, 1997, p. 1600

${ }^{5}$ N. L. Okamoto, M. Inomoto, H. Adachi, H. Takebayashi, H. Inui, Micropillar compression deformation of single crystals of the intermetallic compound $\zeta$-FeZn13, Acta Mater., 65 (2014), 229-239, doi:10.1016/j.actamat.2013.10.065

${ }^{6}$ N. L. Okamoto, D. Kashioka, M. Inomoto, H. Inui, H. Takebayashi, S. Yamaguchi, Compression deformability of $\Gamma$ and $\zeta \mathrm{Fe}-\mathrm{Zn}$ intermetallics to mitigate detachment of brittle intermetallic coating of galvannealed steels, Scr. Mater., 69 (2013) 4, 307-310, doi:10.1016/ j.scriptamat.2013.05.003

${ }^{7}$ G. F. Bastin, F. J. J. van Loo, G. D. Rieck, New compound in the iron-zinc system, Zeitschrift für Met., 65 (1974) 10, 656-660

${ }^{8}$ X. Hu, T. Watanabe, Relationship between the Crystallographic Structure of Electrodeposited Fe-Zn Alloy Film and its Thermal Equilibrium Diagram, Mater. Trans., 42 (2001) 9, 1969-1976, doi:10.2320/matertrans.42.1969

${ }^{9}$ X. Hu, G. Zou, S. J. Dong, M. Y. Lee, J. P. Jung, Y. Zhou, Effects of Steel Coatings on Electrode Life in Resistance Spot Welding of Galvannealed Steel Sheets, Mater. Trans., 51 (2010) 12, 2236-2242, doi:10.2320/matertrans.M2010239

${ }^{10}$ Z. A. Munir, U. Anselmi-Tamburini, M. Ohyanagi, The effect of electric field and pressure on the synthesis and consolidation of materials: A review of the spark plasma sintering method, J. Mater. Sci., 41 (2006) 3, 763-777, doi:10.1007/s10853-006-6555-2

${ }^{11} \mathrm{P}$. R. Munroe, B. Gleeson, The development of Fe-Zn intermetallic compounds in solid $\mathrm{Fe} / \mathrm{Zn}$ and $\mathrm{Fe} / \mathrm{Zn}-\mathrm{Al}$ diffusion couples during short-term annealing at $400{ }^{\circ} \mathrm{C}$, Mater. Sci. Eng. A, 264 (1999) 1-2, 201-209, doi:10.1016/S0921-5093(98)01089-2

${ }^{12}$ J. Mackowiak, N. R. Short, Metallurgy of galvanized coatings, Int. Met. Rev., 24 (1979) 1, 1-19, doi:10.1179/imtr.1979.24.1.1

${ }^{13}$ L. B. McCusker, R. B. Von Dreele, D. E. Cox, D. Louër, P. Scardi, Rietveld refinement guidelines, J. Appl. Crystallogr., 32 (1999) 1, 36-50, doi:10.1107/S0021889898009856

${ }^{14}$ J. K. Brandon, R. Y. Brizard, P. C. Chieh, R. K. McMillan, W. B. Pearson, New refinements of the $\{\gamma\}$ brass type structures Cu5Zn8, Cu5Cd8 and Fe3Zn10, Acta Crystallogr. Sect. B, 30 (1974) 6, 1412-1417, doi:10.1107/S0567740874004997

${ }^{15}$ C. H. E. Belin, R. C. H. Belin, Synthesis and Crystal Structure Determinations in the $\Gamma$ and $\delta$ Phase Domains of the Iron-Zinc System: Electronic and Bonding Analysis of Fe13Zn39 and FeZn10, a Subtle Deviation from the Hume-Rothery Standard?, J. Solid State Chem., 151 (2000) 1, 85-95, doi:10.1006/jssc.2000.8626

${ }^{16}$ A. Johansson, H. Ljung, S. Westman, X-Ray and Neutron Diffraction Studies on Gamma-Ni, Zn and Gamma-Fe, Zn, Acta Chem. Scand., 22 (1968), 2743-2753, doi:10.3891/acta.chem.scand.22-2743

${ }^{17}$ N. L. Okamoto, K. Tanaka, A. Yasuhara, H. Inui, Structure refinement of the delta1p phase in the Fe-Zn system by single-crystal $\mathrm{X}$-ray diffraction combined with scanning transmission electron microscopy, Acta Crystallogr. B Struct. Sci. Cryst. Eng. Mater., 70 (2014) 2, 275-282, doi:10.1107/S2052520613034410 